\title{
Performance of Concrete
}

Resistance of concrete to sulphate and other environmental conditions

\section{A symposium in honour of Thorbergur Thorvaldson}

\section{Technical Editor: E. G. Swenson}

Toronto, University of Toronto Press, 1968. $254 \times 177 \mathrm{~mm}$. pp. x, 243. Canadian Building Series No. 2. Price $\$ 10.00$. SBN 802032087.

This is the first technical volume in the Canadian Building Series, which is sponsored by the Division of Building Research, National Research Council of Canada. (No. 1 in the series was Canada Builds, $1867-1967$ by $\mathrm{T}$. Ritchie, price $\$ 12.50$.) It comprises the papers contributed to a memorial symposium held in Toronto in April 1967 and arranged in honour of Thorbergur Thorvaldson (1883-1965).

The first paper is a review by E. G. Swenson and C. J. Mackenzie of Thorvaldson's own contributions to cement and concrete research. Mr Swenson is the Editor of the present volume and Dr Mackenzie was at the University of Saskatchewan when Thorvaldson was appointed Head of the Chemistry Department there in 1919. Some field exposure tests begun by Dr Mackenzie at that time led to Thorvaldson's interest in the problem of sulphate attack. After examining the information available, Thorvaldson concluded that the right approach was to study first the effect of alkali salts upon the pure compounds found in cement. He recognized at an early stage that some modification to the composition of Portland cement might be needed to achieve adequate sulphate resistance in severe conditions. This led eventually to experimental cement plant 'burns' aimed at reducing $\mathrm{C}_{3} \mathrm{~A}$ content. In the meantime, Thorvaldson had developed the lean mortar bar test. Among the other subjects studied by Thorvaldson were carbonation, effect of salts other than sulphate and steam curing.

The second paper is a review by W. C. Hansen of the chemistry of sulphate-resisting Portland cements. This is followed by F. M. Lea on some studies on the performance of concrete structures in sulphate-bearing environments and B. Mather on field and laboratory studies of the sulphate resistance of concrete.

B. P. Bellport writes on combating sulphate attack on concrete on Bureau of Reclamation projects, G. C. Price and R. Peterson describe experience in sulphate environments in Western Canada and G. J. Verbeck reports field and laboratory studies by the Portland Cement Association on the sulphate resistance of concrete. Sulphate-resisting cement concrete in the Winnipeg Area is discussed by W. D. Hurst, and the performance of ordinary Portland cement concrete in prairie soils of high sulphate content by J. J. Hamilton and G. O. Handerford.

D. C. Tibbetts quotes some examples from Halifax, Nova Scotia, of the performance of concrete in seawater. J. Ryell and P. Smith report case histories of poor concrete durability in highway structures in Ontario, and W. S. Weaver and H. L. Isabelle record observations of sidewalk concrete during fifteen years' exposure. Finally, J. H. Keyser writes on the scaling of concrete by frost action.

Appropriately for a volume dedicated to the memory of Thorvaldson, the papers cover a wide range from precise chemical measurements to practical recommendations for achieving durability on the site. This volume pays direct tribute to him, but also the important indirect tribute of attending unusually closely to a subject which mattered to him, the performance of concrete. 